\title{
Self and Foreign Substances in Organic and Conventional Milk Produced in the Eastern Region of Mexico
}

\author{
Rey Gutiérrez ${ }^{1}$, P. Rosell ${ }^{1,2}$, S. Vega ${ }^{1^{*}}$, Jesús Pérez ${ }^{1}$, Acacia Ramírez ${ }^{1}$, Marta Coronado ${ }^{1}$ \\ ${ }^{1}$ Departamento de Producción Agrícola y Animal, Universidad Autónoma Metropolitana Unidad Xochimilco, D.F. México, México; \\ ${ }^{2}$ Graduate of Master in Agricutural Sciences, Universidad Autónoma Metropolitana Unidad Xochimilco, D.F. México, México. \\ Email: ${ }^{*}$ svega@correo.xoc.uam.mx
}

Received March 20 $0^{\text {th }}, 2013$; revised April 20 ${ }^{\text {th }}, 2013$; accepted April 27 $7^{\text {th }}, 2013$

Copyright (C) 2013 Rey Gutiérrez et al. This is an open access article distributed under the Creative Commons Attribution License, which permits unrestricted use, distribution, and reproduction in any medium, provided the original work is properly cited.

\begin{abstract}
The objective of the present study was to evaluate the physicochemical properties, presence of water and aflatoxin M1, as well as the effect of the time of year (dry or rainy season) to value the quality and safety of conventional and organic raw milk samples. Samples were collected of conventional $(n=12)$ and organic $(n=11)$ raw milk from Tizayuca, Hidalgo and from Tuxpan, Veracruz, respectively. Infrared spectrophotometry and other analytical techniques were employed, approved by the International Dairy Federation for the analysis of the physicochemical properties, the cryoscopy technique for the detection of water addition, and high performance liquid chromatography for the determination of aflatoxin M1. Results showed that there are no significant differences in the components of conventional milk in the season of the year, whereas in organic milk a significant difference $(\mathrm{P}<0.05)$ was observed in acidity during the seasons of the year (rainy and dry), as well as a decrease in the percentage of lactose in the dry season, with a significant difference $(\mathrm{P}<0.05)$. The means of the cryoscopic point of the milk samples complied with the limits established in the Mexican Official Norm $\left(-0.530,-0.560^{\circ} \mathrm{H}\right)$ for milk and no effect was found of the time of year on this variable. Of the milk samples, $50 \%$ of the conventional milk and $54.55 \%$ of organic milk were above the maximum limits permitted for aflatoxin M1, established in Mexico $\left(0.5 \mu \mathrm{g} \cdot \mathrm{Kg}^{-1}\right)$.
\end{abstract}

Keywords: Self and Foreign Substances; Organic Milk; Mexico

\section{Introduction}

Food quality and safety is a topic that concerns and interests the human population, thus the demand for varied, healthy and nutritious foods is increasingly more important [1]. One of the foods with highest nutritional value, after hen eggs, is milk. According to the Norm NOM243-SSAI-2010 [2] of Mexico, milk is the natural secretion of the mammary glands of healthy cows or of any other animal species, excluding the colostrum.

There are presently two forms of milk production, conventional and organic. Conventional agriculture utilizes methods, techniques and inputs (pesticide and fertilizers) that can cause contamination and alteration of soil, water, biodiversity and environment.

In general terms, the organic products can be defined as derivates of a production system that utilizes natural inputs and prohibits the use of pesticides, synthetic fertilizers, antibiotics and transgenic substances [3], and

*Corresponding author. have the characteristic of being more expensive than the conventional products. In Europe, the premium that the consumer pays for organic milk is $42 \%$ higher than that of conventional milk [4].

As part of this tendency, Mexico is in the process of developing organic production systems and new forms of marketing of these products, as they generally are priced $30 \%-50 \%$ higher than the conventional products. Mexico presently occupies fifteenth place in the production of organic foods [4]. In the case of organic milk production, its development has been slow; however, the Mexico City market now offers four brands of organic milk.

The financial data of the differences of the organic products with respect to the conventional ones assume characteristics that are more highly valued by the consumer, for example, higher content of nutrients and functional substances, and lower content of undesirable substances such as pesticides, heavy metals and aflatoxins, among others. Some studies have attempted to explain the presence of these substances in foods. For the par- 
ticular case of milk, Espinoza et al. [1] state that organic milk is more susceptible to contamination by mycotoxins derived from molds than conventional milk, given that the former has not been treated with chemical agents for the control of these organisms. Milk may be contaminated with mycotoxins, the most important of which is aflatoxin M1 (AFM1). The AFM1 is a toxin found in animal milk and is considered to be a possible carcinogen of importance to human health [5].

Both conventional and organic milk should provide the population with first quality nutrients that contribute to growth and development, and be free of foreign substances that endanger the health of consumers. Therefore, the objective of the present study was to evaluate the physicochemical properties (acidity, $\mathrm{pH}$, fat, protein, lactose, total solids, non-fat solids and casein), along with the presence of foreign substances (water and aflatoxin M1) and the effect of time of year (dry or rainy) on the quality and safety of organic and conventional raw milk samples.

\section{Materials and Methods}

\subsection{Study Zones}

Two dairy production units were selected, one with conventional production located in Tizayuca, Hidalgo, Mexico and the other in Tuxpan, Veracruz, Mexico, characterized for having an organic production system. The municipality of Tizayuca, Hidalgo is located at a latitude of $19^{\circ} 50^{\prime} 14^{\prime \prime}$; its longitude is $98^{\circ} 59^{\prime} 12^{\prime \prime} \mathrm{W}$ and its altitude is 2260 masl [6]. The municipality of Tuxpan in the state of Veracruz has a tropical climate $\left(24.9^{\circ} \mathrm{C}\right)$, north latitude of $21^{\circ} 4^{\prime} 36^{\prime \prime}$, west latitude of $97^{\circ} 27^{\prime} 34^{\prime \prime}$, with an altitude of 10 masl and annual rainfall of $1.241 \mathrm{~mm}$ [7].

\subsection{Collection and Preservation of Samples}

Samples were collected monthly during one year, of raw cow's milk from two dairy production units. The first sample was obtained from an intensive production unit for Holstein cattle with a diet based on a mixture of alfalfa, silage and concentrate; and the second was obtained from an organic production system with cattle that were a cross of Zebu with Holstein, fed with fresh forage (grazing) and a portion of concentrate $(0.5 \mathrm{Kg})$ during milking.

The total of samples was 23 (12 samples of conventional milk and 11 of organic milk), with a minimum volume per sample of one liter, previously homogenized from the original samples (raw milk, obtained from 50 cows), following the criteria established by the International Dairy Federation and the Norm NMX-F-718COFOCALEC-2006 [8,9].

The sampling of conventional and organic milk was made in different periods, due to the disposition and location of the milk production units selected for the present study.

The samples were preserved during their transport (from the collection site to the analysis laboratory) at a temperature of $0^{\circ} \mathrm{C}$ to $4^{\circ} \mathrm{C}$ in glass containers without exposure to direct sunlight $[8,9]$.

\subsection{Analysis of Physical Characteristics of the Milk}

The determination of $\mathrm{pH}$ of the milk was made by directly measuring with the scale of the potentiometer calibrated with a buffer solution of $\mathrm{pH} 4$ to 7 . The value of acidity was determined by means of the titration method with an alkaline solution of $\mathrm{NaOH}(0.1 \mathrm{~N}, \mathrm{pH} 13)$.

\subsection{Analysis of Chemical Characteristics of the Milk}

The analysis of the content of fat, protein and lactose of the raw organic milk samples was made by means of infrared spectroscopy (Milko-scan, Denmark). The total solids (TS) resulted from the sum of the content of fat, protein and lactose, whereas the non-fat solids (NFS) were the sum of protein and lactose. The milk casein was determined by means of the coagulation method through the acid procedure [10].

\subsection{Analysis for the Determination of Foreign Substances in Milk}

The analysis to determine the addition of water in milk was made by cryoscopy including the sudden crystallization by mechanical vibration, until reaching the freezing point of the sample [11].

The AFM1 content was determined by high performance liquid chromatography with fluorescent detector using a reverse phase column. The extraction in solid phase was made over a $\mathrm{C} 18$ column and another of silica column. The AFM1 was derivatized with trifluoroacetic acid [12].

\subsection{Statistical Analysis}

The data bases were obtained for each one of the physicochemical characteristics of the milk, and a descriptive statistical analysis (mean, standard deviation and coefficient of variation) was made. Then a Student's t-test was applied, using the SPSS software version 20.0 to know the significance of the milk composition with respect to time of year (dry or rainy season).

With the results of the determination of the cryoscopic point and of the AFM1 content in conventional and organic milk samples, a descriptive statistical analysis was made along with a Student's t-test; for the analysis of 
AFM1 the technique of means and percentiles was also used, using the software SPSS version 20.0 to Windows [13].

\section{Results and Discussion}

\subsection{Values of Acidity and $\mathrm{pH}$ of milk}

In Table 1 it can be observed that conventional raw milk presented acidity values that vary from $1.6 \%$ to $1.9 \%$ with a standard deviation (SD) of 0.11 and a coefficient of variation $(\mathrm{CV})$ of $6.07 \%$, the mean of this characteristic being $1.77 \%$, whose value is within the maximum limit (1.7\%) established by the NOM-155 of Mexico [14]. In the samples taken in the months of June 2009, March and May 2010, values above the maximum indicated for this variable (1.9\%) appeared. The minimum and maximum values of the percentage of acidity in organic milk were $1.3 \%$ and $2.0 \%$ with a SD of 0.23 and a CV of $14.25 \%$, which indicates that the values, along with the mean $(1.6 \%)$, are above the limits indicated by the NOM155 , in addition to presenting high variation during the study.

Table 1 shows the values of $\mathrm{pH}$ of the conventional milk samples, which are in an interval of 6.6 to 6.9 with a mean of 6.69 , a SD of 1.10 and a CV of $1.54 \%$. The

Table 1. Values of acidity and pH of conventional raw milk from Tizayuca, Hidalgo and of organic raw milk from Tuxpan, Veracruz.

\begin{tabular}{cccccc}
\hline \multicolumn{5}{c}{ Conventional milk } & \multicolumn{5}{c}{ Organic milk } \\
\hline Sample & Acidity (\%) & $\mathrm{pH}$ & Sample & Acidity (\%) & $\mathrm{pH}$ \\
\hline 1 (Feb-09) & 1.7 & 6.7 & 1 (Oct-08) & 1.4 & 6.8 \\
2 (Mar-09) & 1.8 & 6.8 & 2 (Dec-08) & 1.6 & 6.8 \\
3 (Apr-09) & 1.8 & 6.9 & 3 (Jan-09) & 1.4 & 6.9 \\
4 (May-09) & 1.8 & 6.8 & 4 (Mar-09) & 1.9 & 6.7 \\
5 (Jun-09) & 1.9 & 6.6 & 5 (Apr-09) & 1.7 & 6.7 \\
6 (Jul-09) & 1.6 & 6.7 & 6 (May-09) & 1.5 & 6.7 \\
7 (Dec-09) & 1.6 & 6.6 & 7 (Jun-09) & 1.3 & 6.8 \\
8 (Jan-10) & 1.8 & 6.7 & 8 (Jul-09) & 1.4 & 6.8 \\
9 (Mar-10) & 1.9 & 6.6 & 9 (Sep-09) & 1.6 & 6.7 \\
10 (Apr-10) & 1.7 & 6.7 & 10 (Nov-09) & 1.8 & 6.8 \\
11 (May-10) & 1.9 & 6.6 & 11 (Dec-09) & 2.0 & 6.4 \\
12 (May-10) & 1.7 & 6.6 & & & \\
X & 1.77 & 6.69 & X & 1.6 & 6.73 \\
SD & 0.11 & 0.10 & DS & 0.23 & 0.13 \\
CV & 6.07 & 1.54 & CV & 14.25 & 1.88 \\
\hline M & & & &
\end{tabular}

$\mathrm{X}$ : Mean; SD: Standard deviation; CV: Coefficient of variation. sample of April of 2009 presented the maximum value (6.9), which does not comply with the Mexican Norm for $\mathrm{pH}$ in raw milk. The minimum and maximum values of $\mathrm{pH}$ in the organic milk samples were of 6.4 and 6.9, which correspond to the samples collected in the months of December and January of 2009, respectively. The mean of this variable (6.73) remains within the limit.

In Pakistan a study was made of the physical characteristics in samples of raw cow's milk. The reported values of titratable acidity oscillated in an interval of $0.81 \%$ and $1.84 \%$, with $\mathrm{pH}$ values of $6.59 \pm 0.59$, which differ from what was found in this study [15].

NOM-155-SCFI-2003 [14] indicates that the limit for acidity in raw milk is $1.4 \%-1.7 \%$, and that this value is affected by the chemical enzymatic complex of the milk content and to slow microbial growth, leaving the value outside of the established values. Similarly, the acidity can be increased by the storage time under inadequate conditions of refrigeration.

Of the physicochemical characteristics analyzed in the conventional and organic milk samples, acidity had the highest variation $(6.07 \%, 14.25 \%$, respectively). Results show that the time of year has an effect on the percentage of acidity in the organic milk samples $(\mathrm{P}<0.05)$.

\subsection{Milk Composition}

Table 2 shows the percentage values of fat, protein, lactose, TS, NFS and casein obtained from the conventional and organic milk samples.

\subsection{Conventional Milk}

The minimum and maximum percent value for the fat variable in conventional milk was 2.62 to 4.3 , the values lower than 3\% of the months of April and May of 2009 do not comply with the requirements established in the Mexican Norm [14]. The differences of values obtained result in a SD of 0.48 and $\mathrm{CV}$ of $14.47 \%$, which indicates that fat is the milk component that varies the most throughout the year.

The average of the butyric fat was $3.29 \%$, which falls in the interval by the NOM-155 (3.0\% minimum), although in the months of April and May of 2009, it was below the stipulated minimum, which may be a result of the modification of the diet of the animals. The results of fat of this study differ from those reported by Guevara et al. [16], who conducted a study to know the effect of the time of year on the percentage of fat in milk produced by stabled Holstein cows. The results showed that in the dry season (April), milk with 3.73\% fat was produced, and in the rainy season (July), the milk fat content was 3.99\%, which indicates highly significant differences $(\mathrm{P}<0.01)$ for the milk fat content.

The minimum and maximum protein values obtained 
Table 2. Composition of conventional raw milk from Tizayuca, Hidalgo and of organic raw milk from Tuxpan, Veracruz.

\begin{tabular}{|c|c|c|c|c|c|c|}
\hline \multirow{2}{*}{ Sample } & \multicolumn{6}{|c|}{ Conventional milk } \\
\hline & Fat $(\%)$ & Protein $(\%)$ & Lactose (\%) & TS (\%) & NFS (\%) & Casein $(\%)$ \\
\hline 1 (Feb-09) & 3.38 & 3.26 & 4.86 & 12.2 & 8.83 & 2.39 \\
\hline 2 (Mar-09) & 3.35 & 3.18 & 4.86 & 12.09 & 8.74 & 2.23 \\
\hline 3 (Apr-09) & 2.62 & 3.33 & 4.71 & 11.36 & 8.74 & 1.71 \\
\hline 4 (May-09) & 2.71 & 3.18 & 4.63 & 11.19 & 8.47 & 1.76 \\
\hline 5 (Jun-09) & 3.04 & 3.15 & 4.9 & 11.78 & 8.74 & 2.21 \\
\hline 6 (Jul-09) & 4.01 & 3.03 & 4.83 & 12.57 & 8.56 & 1.99 \\
\hline 7 (Dec-09) & 3.24 & 3.15 & 4.87 & 11.96 & 8.72 & 2.39 \\
\hline $8($ Jan-10) & 3.4 & 3.19 & 4.87 & 12.16 & 8.76 & 2.33 \\
\hline 9 (Mar-10) & 3.06 & 3.15 & 4.84 & 11.74 & 8.69 & 2.25 \\
\hline $10($ Apr-10) & 3.21 & 3.1 & 4.88 & 11.88 & 8.68 & 2.31 \\
\hline 11 (May-10) & 4.3 & 3.18 & 5.03 & 13.2 & 8.91 & 1.94 \\
\hline 12 (May-10) & 3.15 & 3.05 & 4.88 & 11.78 & 8.63 & 2.29 \\
\hline $\mathrm{X}$ & 3.29 & 3.16 & 4.85 & 11.9 & 8.70 & 2.15 \\
\hline SD & 0.48 & 0.08 & 0.10 & 0.53 & 0.11 & 0.24 \\
\hline \multirow[t]{2}{*}{$\mathrm{CV}$} & 14.47 & 2.59 & 2.03 & 4.42 & 1.32 & 11.08 \\
\hline & \multicolumn{6}{|c|}{ Organic milk } \\
\hline 1 (Oct-08) & 4.38 & 3.59 & 4.56 & 13.24 & 8.86 & 2.7 \\
\hline 2 (Dec-08) & 4.54 & 3.64 & 4.52 & 13.41 & 8.87 & 2.6 \\
\hline $3($ Jan-09) & 4.13 & 3.4 & 4.47 & 12.7 & 8.57 & 2.46 \\
\hline 4 (Mar-09) & 5.48 & 3.46 & 4.54 & 14.18 & 8.69 & 2.37 \\
\hline 5 (Apr-09) & 2.88 & 3.29 & 4.82 & 11.69 & 8.81 & 2.52 \\
\hline 6 (May-09) & 2.82 & 3.26 & 4.87 & 11.58 & 8.78 & 2.43 \\
\hline 7 (Jun-09) & 2.76 & 3.11 & 4.93 & 11.51 & 8.75 & 2.34 \\
\hline 8 (Jul-09) & 3.37 & 3.42 & 5.15 & 12.64 & 9.27 & 2.59 \\
\hline 9 (Sep-09) & 3.98 & 3.6 & 4.93 & 13.24 & 9.26 & 2.67 \\
\hline 10 (Nov-09) & 4.59 & 3.84 & 4.72 & 13.85 & 9.26 & 2.74 \\
\hline 11 (Dec-09) & 3.98 & 3.72 & 4.72 & 13.11 & 9.14 & 2.55 \\
\hline $\mathrm{X}$ & 3.90 & 3.48 & 4.75 & 12.83 & 8.93 & 2.54 \\
\hline SD & 0.86 & 0.22 & 0.21 & 0.91 & 0.25 & 0.13 \\
\hline $\mathrm{CV}$ & 22.15 & 6.23 & 4.51 & 7.09 & 2.83 & 5.22 \\
\hline
\end{tabular}

TS: Total solids; NFS: Non-fat solids; X: Mean; SD: Standard deviation; CV: Coefficient of variation.

from the conventional milk samples were $3.03 \%$ and $3.33 \%$, with a SD of 0.08 and a CV of $2.59 \%$. The average of this characteristic was $3.16 \%$, whose value complies with the limits established in NOM-155, along with the mean of the dry season and rainy season $(3.19 \%$ and $3.12 \%$, respectively).
The difference of the values of casein of the conventional milk samples showed a SD of 0.24 and a CV of $11.08 \%$, with an average of $2.15 \%$, thus complying with the abovementioned norm; this component showed an important variation throughout the year. In the rainy season the casein content presented low values compared 
to the dry season, which may be a result of the change of feed and/or the lactation period [17].

The minimum and maximum value of lactose in the conventional milk samples analyzed in this study was $4.63 \%$ and $5.03 \%$, with a SD of 0.10 and a CV of $2.03 \%$. The average of this variable was $4.84 \%$, which is within the limits established by NOM-155, as well as the mean of lactose in the dry season (4.84\%) and rainy season $(4.85 \%)$.

The information obtained in this experiment is very similar to what was obtained by Castelán et al. [18], who evaluated the quality of raw milk from the center of Mexico during 3 periods of the year. All of the samples presented levels higher than $3 \%$ of fat and protein, and a minimum of $4.3 \%$ in lactose content, observing significant differences $(\mathrm{P}<0.05)$ between periods in fat content, which coincides with the higher production of forage in the rainy season.

Some other authors have reported values similar to those of this experiment with respect to the content of fat, protein and lactose in raw milk, such is the case of Morales and María [19] in Chile, who studied milk produced by Holstein cows $(3.6 \%, 3.2 \%$ and $4.7 \%)$, respectively. NOM-155 established $3 \%$ as minimum for the fat and protein content in milk.

The mean of the content of TS $(11.99 \%)$ is within the minimum limit established by NOM-155. The values for this variable gave a SD of 0.53 and a $\mathrm{CV}$ of $4.42 \%$. Of the twelve milk samples studied, only five comply with this Norm and coincide with the months in which the content of fat and casein were lower.

It should be mentioned that July of 2009 (rainy season) registered the highest rainfall of the year $\left(114.7 \mathrm{~mm}^{3}\right)$, as did the percentages of fat and TS of the milk sample taken in the same month. Similar results have been observed by Bernal et al. [20] in the evaluation of the physicochemical quality of milk produced in two zones of the state of Mexico, observing significant differences $(\mathrm{P}<0.05)$ in the content of fat and TS per sampling period.

The content of NFS of the conventional milk samples remained within the limits established by the Official Mexican Norm of physicochemical specifications in dairy products [14]. From the above it can be affirmed that the characteristics that fluctuated the most during the sampling period (February, 2009 to May, 2010) were the percentage of fat and casein with variations of $14.47 \%$ and $11.08 \%$, respectively. The study demonstrated that the rainy or dry seasons do not influence the milk quality produced from stabled cows $(\mathrm{P} \geq 0.05)$.

\subsection{Organic Milk}

In Table 2 it is observed that the average of fat in or- ganic milk was $3.9 \%$, complying with the limits established in NOM-155. A minimum and maximum value of $2.76 \%$ and $5.48 \%$ was obtained, with a SD of 0.86 and a variation of $22.15 \%$. However, in the months of April, May and June (rainy season), values were below those established in the Mexican Norm of physicochemical specifications in dairy products [14]. The change and type of food for the cattle, the stage of maturity and size of the forage influenced the milk fat content, along with the stage of lactation, given that at the onset the content of fat and protein were high, later decreased and gradually increased at the end [18]. This behavior was observed throughout the sampling made for the present study (October, 2008 to December, 2009).

The minimum and maximum percent value for protein content was 3.11 and 3.72 with a SD of 0.22 and $\mathrm{CV}$ of $6.23 \%$. The mean of this variable $(3.48 \%)$ and the means of the rainy and dry season $(3.40 \%$ and $3.56 \%$, respectively) are found within the limit established by the Mexican Norm. The results of this study can be supported by what was observed by Morales and María [19], who studied the factors that affect the season of the year on the protein content, given that this value tends to increase during the dry season, just as in the rainy months the fat may average as much as $0.4 \%$ less than in the dry season.

Comerón et al. [21] made an evaluation of the quality of organic milk samples during two years, including three periods (autumn, winter and spring), and feeding the animals (Holstein cows) with grass and concentrate. The fat content for the first year (1997) was 3.53\%, $3.09 \%$ protein, $1.5 \%$ to $1.7 \%$ in acidity and with a $\mathrm{pH}$ that fluctuated between 6.6 and 6.8 ; in the second year (1998) $3.41 \%$ of fat, $3.13 \%$ of protein, $1.5 \%$ to $1.7 \%$ of acidity and a value of 6.7 for $\mathrm{pH}$ was observed. Their results were similar to those of this study.

Table 2 shows the values of the casein content of the organic raw milk samples, the SD (0.13) and the CV $(5.22 \%)$. Both the casein content of the samples and the mean obtained $(2.54 \%)$ fall in the interval marked by NOM-155 (2.4\% minimum).

The minimum and maximum percent value observed in the content of TS was 11.51 and 14.18. The difference gives a SD of 0.91 and a CV of $7.09 \%$. The mean was $12.83 \%$, complying with the requirements. However, in the months of April, May and June (rainy season), values below those established in the Mexican Norm were observed. The average value of NFS was $8.93 \%$, which indicated compliance with NOM-155 (8.3\% minimum). It was determined that the self substances of the organic milk that varied the most during the study were: fat $(232.15 \%)$, protein $(6.23 \%)$ and TS $(7.09 \%)$, due to the fact that the environmental conditions (temperature and relative humidity) vary the most and alter physiological 
mechanisms of the animals, which is reflected in the milk production and composition [17].

Results showed that the percentage of lactose in the organic milk samples expressed a significance of $95 \%(\mathrm{P}$ $<0.05)$.

\subsection{Foreign Substances in Milk}

\subsubsection{Water}

Figure 1 shows the behavior of the cryoscopic point of conventional milk (February, 2009 to May, 2010) and of the organic milk samples collected during the period of October, 2008 to December, 2009.

The mean of the cryoscopic point $\left(-0.545^{\circ} \mathrm{H}\right)$ of the conventional milk samples is found within the parameters established by NOM-155, and only the sample of May of 2009 presented a cryoscopic point of $-0.533^{\circ} \mathrm{H}$, due to a possible addition of water, given that in the same sample a decrease was observed in the content of fat, casein and TS, product of a possible dilution. The difference of these values showed a SD of 0.01 and a CV of $1.2 \%$, which indicated that the cryoscopic point of the conventional milk was stable throughout the year.

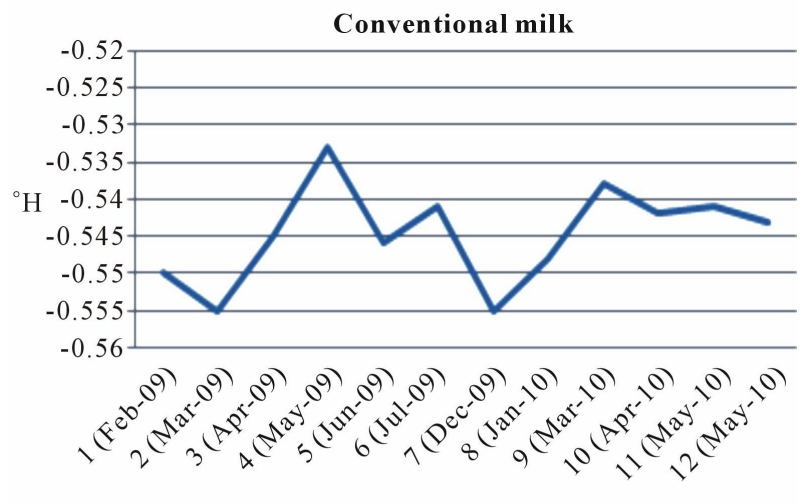

Sample (month)

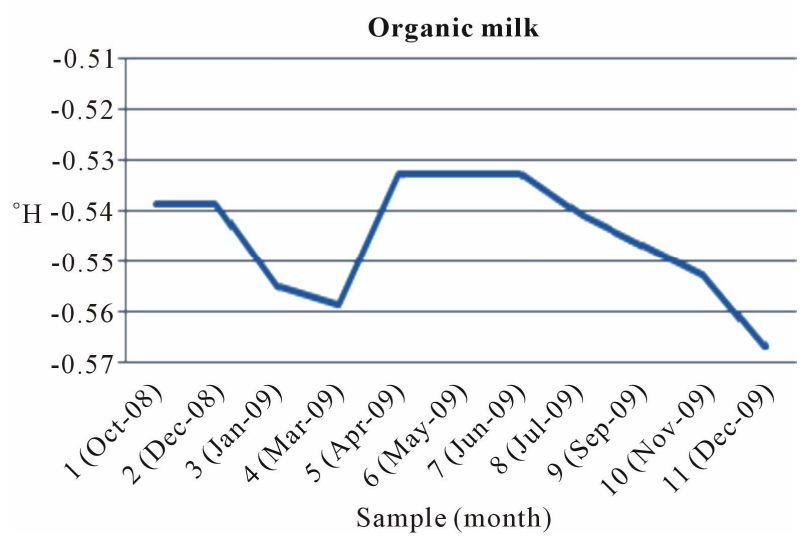

Figure 1.Cryoscopic point in conventional raw milk samples of Tizayuca, Hidalgo and of raw organic milk from Tuxpan, Veracruz (rainy season from May to October and dry season from November to April).
The data of this study were different from what was informed in 2007 by Bernal et al. [20], for two regions of the state of Mexico, where they found that $6.4 \%$ of the samples studied presented the addition of water during the dry season, when there is a decrease in the volume of milk produced, due to the poor body condition of the animals resulting from the limitation of feed with respect to the rainy season.

Based on Figure 1, it was observed that $36.36 \%$ of the samples were outside of the limits established in NOM155 . However, the mean $\left(-0.546^{\circ} \mathrm{H}\right)$ of this variable remained within the limits stipulated by the legislation. Similarly, it was observed that the SD obtained was 0.01 and the $\mathrm{CV}$ was $2.11 \%$. The milk sample collected in December presented the lowest value $(-0.567)$, which is related to the percentage of acidity and the $\mathrm{pH}$ value of the same sample, due possibly to the presence of microorganisms in the milk. Guevara et al. [16] inform that the cryoscopic point can be affected by the acidification of the milk, in which case the cryoscopic point is lowered.

The cryospcopic point of milk is affected by the demands of the market and by the conditions of the different seasons of the year [20]. However, in the present study the cryoscopic point did not present significant differences between the dry and rainy seasons.

\subsubsection{Aflatoxin M1}

In Table 3 it can be observed that in the months of February (2009) and May (2010) no aflatoxin M1 (AFM1) was found in the conventional milk samples. However, $66.66 \%$ of the samples was higher than the Maximum Permissible Limit (MPL) established in the European Union (EU) $\left(0.05 \mu \mathrm{g} \cdot \mathrm{Kg}^{-1}\right)$ and $50 \%$ was higher than the MPL for Mexico $\left(0.5 \mu \mathrm{g} \cdot \mathrm{Kg}^{-1}\right)$ [22]. High levels of AFM1 were observed in the samples taken in the rainy season.

Agricultural production is affected by over $25 \%$ with the presence of some type of mycotoxins, thus it is to be expected that violation levels of MPL are found for AFM1 in milk for human consumption [23].

In Mexico Pérez [24] carried out a study with raw and pasteurized milk, finding that $50 \%$ and $60 \%$ of the samples were over the established limit for the European Union $\left(0.05 \mu \mathrm{g} \cdot \mathrm{Kg}^{-1}\right)$; obtaining medians for raw milk of $16.21 \mu \mathrm{g} \cdot \mathrm{Kg}^{-1}$ and $16.1 \mu \mathrm{g} \cdot \mathrm{Kg}^{-1}$ for pasteurized milk.

The results of this study were different from those informed by Reyes et al. [25], who analyzed 40 samples of raw milk from the state of Jalisco, Mexico. The AFM1 had an occurrence of $80 \%$, the levels detected fluctuated between 0.006 to $0.065 \mu \mathrm{g} \cdot \mathrm{Kg}^{-1}$ (mean $=0.023 \pm 0.016$ $\left.\mu \mathrm{g} \cdot \mathrm{Kg}^{-1}\right)$. None of the samples was over the limit permitted by the regulation $\left(0.5 \mu \mathrm{g} \cdot \mathrm{Kg}^{-1}\right)$. They concluded that in the region of study the levels of AFM1 in milk do not represent a risk for human health. 
Table 3. Content of AFM1 $\left(\mu \mathrm{g} \cdot \mathrm{Kg}^{-1}\right)$ in conventional and raw milk samples.

\begin{tabular}{|c|c|c|c|}
\hline \multicolumn{2}{|c|}{ Conventional milk } & \multicolumn{2}{|c|}{ Organic milk } \\
\hline Sample & AFM1 $(\mu \mathrm{g} / \mathrm{Kg})$ & Sample & AFM1 $(\mu \mathrm{g} / \mathrm{Kg})$ \\
\hline 1 (Feb-09) & 0.04 & 1 (Oct-08) & 7.66 \\
\hline 2 (Mar-09) & 0.09 & $2($ Dec-08) & 6.42 \\
\hline 3 (Apr-09) & 0.99 & 3 (Jan-09) & 2.59 \\
\hline 4 (May-09) & 1.15 & 4 (Mar-09) & 0.00 \\
\hline 5 (Jun-09) & 0.38 & 5 (Apr-09) & 0.00 \\
\hline 6 (Jul-09) & 0.73 & 6 (May-09) & 0.53 \\
\hline 7 (Dec-09) & 0.00 & 7 (Jun-09) & 0.00 \\
\hline 8 (Jan-10) & 3.29 & 8 (Jul-09) & 0.00 \\
\hline 9 (Mar-10) & 0.63 & 9 (Sep-09) & 0.23 \\
\hline $10($ Apr-10) & 3.81 & 10 (Nov-09) & 1.23 \\
\hline 11 (May-10) & 0.03 & 11 (Dec-09) & 0.88 \\
\hline 12 (May-10) & 0.00 & & \\
\hline $\mathrm{X}$ & 0.93 & $\mathrm{X}$ & 1.78 \\
\hline $\mathrm{SD}$ & 1.29 & DS & 2.73 \\
\hline $\mathrm{CV}$ & 139.27 & $\mathrm{CV}$ & 153.67 \\
\hline
\end{tabular}

AFM1: aflatoxin M1; X: Mean; SD: Standard deviation; CV: Coefficient of variation.

In the organic milk samples studied, $63.63 \%$ presented AFM1 levels higher than the limits established by the EU and $45.45 \%$ presented levels higher than the values established in Mexico for NOM-184-SSA1-2002 (0.5 $\left.\mu \mathrm{g} \cdot \mathrm{Kg}^{-1}\right)$ [26].

In Table 3 it can be observed that in the months of December, 2008 and January, 2009 (dry season), as well as June and July 2009 (rainy season) no AFM1 was detected. In October of 2008 (rainy season) the highest content of AFM1 appeared $\left(7.66 \mu \mathrm{g} \cdot \mathrm{Kg}^{-1}\right)$.

In 2007 Pérez [24] determined the presence of AFM1 in ultrapasteurized organic milk sold in Mexico City, and found that $20 \%$ of the samples presented AFM1 with values higher than the MPL of the EU $\left(0.05 \mu \mathrm{g} \cdot \mathrm{Kg}^{-1}\right)$, which is similar to what was observed in the raw organic milk samples of this investigation.

In Mexico, studies referring to the presence of AF1 in organic milk have not been published until now. However, work has been carried out at the national level on the effect of time of year on the presence of AFM1 in conventional milk. Montañoet al. [27] analyzed 20 milk samples from five different communities of the Municipality of Achacachi, Bolivia, in two periods: rainy (April, May) and dry season (August, September). Of the 20 samples, 5 were positive with levels higher than the MPL $\left(0.05 \mu \mathrm{g} \cdot \mathrm{Kg}^{-1}\right), 4$ in the rainy season $(0.18,0.12,0.089$, $0.077 \mu \mathrm{g} \cdot \mathrm{Kg}^{-1}$, respectively) and one in the dry season $\left(0.05 \mu \mathrm{g} \cdot \mathrm{Kg}^{-1}\right)$.

In this investigation, $54.55 \%$ of the organic milk samples and $50 \%$ of the conventional milk samples were above the MPL established in Mexico $\left(0.5 \mu \mathrm{g} \cdot \mathrm{Kg}^{-1}\right)$.

It was observed that in the rainy season (April to October), $21.73 \%$ of the conventional and organic milk samples were found to be below the MPL $\left(0.05 \mu \mathrm{g} \cdot \mathrm{Kg}^{-1}\right)$ for aflatoxin $\mathrm{M} 1$ and $26.08 \%$ in the dry season. However, $30.43 \%$ of the conventional and organic milk samples exceeded the AFM1 content in the rainy season and $21.74 \%$ in the dry season, according to NOM-184-SSA12002 [26].

With the analysis of means and percentiles, it was observed that the median of the conventional milk samples was $0.505 \mu \mathrm{g} \cdot \mathrm{Kg}^{-1}$ and is $1 \%$ higher than the MPL established in Mexico, whereas the mean of the organic milk samples was $0.530 \mu \mathrm{g} \cdot \mathrm{Kg}^{-1}$ and is $6 \%$ higher than $0.5 \mu \mathrm{g} \cdot \mathrm{Kg}^{-1}$.

\section{Conclusions}

In the composition of self substances of raw milk obtained from a stable production system, no effect from the time of year was observed. However, the time of year did affect the lactose content of organic milk, presenting a reduction of these values in the dry season with a significance of $95 \%$.

The means of the cryoscopic point of the conventional and organic milk samples analyzed $\left(-0.545\right.$ and $-0.546^{\circ} \mathrm{H}$, respectively) remained within the range established by the Mexican Official Norm for milk, however, five samples were observed with values higher than the established limits.

Of the total of the raw milk samples (conventional and organic), $47.83 \%$ presented AFM1 levels that were higher than the value established by NOM 184-SSA1- 2002.

\section{Acknowledgements}

We would like to thank the Consejo Nacional de Ciencia y Tecnología (CONACYT) of Mexico and the Universidad Autónoma Metropolitana Unidad Xochimilco, for financing this project, without which the project would have been impossible.

\section{REFERENCES}

[1] J. Espinoza, A. Palacios, N. Ávila, A. Guillen, R. Luna, R. Ortega and B. Murillo, "La Ganadería Orgánica, una Alternativa de Desarrollo Pecuario para Algunas Regiones de México: Una Revisión," Interciencia, Vol. 32, No. 6, 2007, pp. 385-390.

[2] NOM-243-SSA1-2010, "Productos y Servicios. Leche, Fórmula Láctea, Producto Lácteo Combinado y Deriva- 
dos Lácteos. Disposiciones y Especificaciones Sanitarias. Método de Prueba," Norma Oficial Mexicana, México, 2010.

[3] FAO, "Agricultura Orgánica: Impactos Mundiales," Extractos de la Reunión del Comité de la Agricultura de la FAO, Roma, 1999, pp. 1-12.

http://www.fao.org/docrep/meeting/X0075s.htm

[4] J. E. García, "Situación y Perspectivas de la Agricultura Orgánica en México,” 2001, pp. 116-124.

http://web.catie.ac.cr/informacion/rmip/rev64/agri organi ca.pdf

[5] C. Oliveira, J. Rosmaninho and R. Rosim, "Aflatoxin M1 and Cyclopiazonic Acid in Fluid Milk Traded in Sao Paulo, Brazil," Food Additives and Contaminants, Vol. 23, No. 2, 2006, pp. 196-201. doi:10.1080/02652030500398379

[6] INEGI, “Anuario Estadístico de Veracruz de Ignacio de la llave. Gobierno del Estado de Veracruz," Instituto Nacional de Estadística Geográfica e Informática, Vol. 3, 2007, pp. 187-190.

[7] INEGI, "Producción de Leche," Instituto Nacional de Estadística Geográfica e Informática, 2007.

http://w4.siap.gob.mx/sispro/portales/pecuarios/lechebovi no/situacion/descripcion.pdf

[8] IDF/FIL (International DairyFederation/Federación Internacional de Lechería), "Métodos Estándares Para la Toma de Muestras de Leche y Productos Lácteos," FIL-IDF 50 B, Belgium, 1995.

[9] NMX-F-718-COFOCALEC-2006, "Sistema Producto Leche Alimentos Lácteos. Guía Para el Muestreo de Leche y Productos Lácteos," Consejo para el Fomento de la Calidad de la Leche y sus Derivados A.C., 2006.

[10] IDF/FIL (International DairyFederation/Federación Internacional de Lechería), "Determinación Simultanea de la Materia Grasa, Proteína y Lactosa por Espectroscopía Infrarroja," FIL-IDF 141A, Belgium, 1990.

[11] IDF/FIL (International DairyFederation/Federación Internacional de Lechería), "Determinación del Punto Crioscópico (Congelación) de la Leche," FIL-IDF 108 B, Belgium, 1991.

[12] AOAC, Official Method 986.16, "Aflatoxins M1 y M2 in Fluid Milk. Liquid Chromatographic Method," Association of Official Analytical Chemists, Arlington, 1995.

[13] A. V. Clark and S. May, "Computer Aided Multivariate Analysis," 4th Edition, Chapman and Hall, Boca Raton, 2004.

[14] NOM-155-SCFI-2012, "Leche-Denominaciones, Especificaciones Fisicoquímicas, Información Comercial y Métodos de Prueba,” Norma Oficial Mexicana, 2012.

[15] Mohammad, K. Hamayun, H. Syed and K. Rasool, "Physicochemical Characteristics of Various Milk Samples Availables in Pakistan University of Zhejiang B," Science and Technology, Vol. 9, No. 7, 2008, pp. 546-551.
[16] L. Guevara, T. Rodríguez, C. Pacheco and O. Verde, "Factores Climáticos Sobre Índices Fisiológicos y Producción de Leche en Vacas Lechera," Veterinaria Tropical, Vol. 5, 1980, pp. 51-68.

[17] M. Martínez, L. Andrés and J. Sánchez, "Factores Nutricionales que Afectan a la Composición de la Leche," 2007.

http://www.engormix.com/factores_nutricionales_afectan _composicion_s_articulos_1466_GDL.htm

[18] Castelán, L. Bernal, M. Rojas, A. Rosales, C. Vázquez and A. Espinoza, "Determinación de la Calidad Fisicoquímica de Leche Producida en Sistemas Campesinos del Centro de México-Perspectivas de Ingreso al Mercado Formal de Lácteos," Universidad Autónoma del Estado de México, 2006.

[19] S. Morales and S. María, "Factores que Afectan la Composición de la Leche," Facultad de Ciencias Veterinarias y Pecuarias, Vol. 5, No. 1, 1999.

[20] L. Bernal, M. Rojas, C. Vázquez, A. Espinoza, J. Estrada and O. Castelán, "Assessment of the Physicochemical Quality of the Raw Milk Produced in Smallholder Dairy Systems in Two Regions of the State of Mexico," Veterinaria México, Vol. 38, No. 4, 2007, pp. 395-407.

[21] E. Comerón, N. Andreo, C. Salto, L. Romero, L. Calvinho, M. Maciel, A. Abdala and D. Vottero, "Leche y Lácteos Orgánicos Certificados: Experiencia en Productos e Industrialización,” Tecnología de Alimentos, 1999. http://rafaela.inta.gov.ar/productores97_98/p57.htm

[22] FAO, "Reglamentos a Nivel Mundial Para las Micotoxinas en los Alimentos y en las Raciones en el año 2003. Alimentación y Nutrición," 2004. doi:10.1631/jzus.B0820052 http://www.fao.org/es/ESN/index_en.stm

[23] G. Urbán, J. Pérez, F. Martínez, R. Gutiérrez, S. Vega, M. Coronado and A. Escobar, "Aflatoxina M1 en Leche y Queso de Cabra Producidos en Apaseo el Grande, Guanajuato," Revista Salud Animal, Vol. 32, No. 2, 2010, pp. 82-84.

[24] Pérez, "Determinación de Aflatoxina M1 en Quesos y Leches Cruda, Ultrapasteurizada y Orgánica que se Comercializan en la Ciudad de México," Tesis Maestría en Ciencias Agropecuarias, Universidad Autónoma Metropolitana, 2007.

[25] W. Reyes, S. Martínez, V. Espinosa, M. Nathal, E. De Lucas and F. Rojo, "Total Aflatoxins in Cows Feed and AFM1 in Milk in Dairy Herds from Jalisco State," TécPecMex, Vol. 47, No. 2, 2009, pp. 223-230.

[26] NOM-184-SSA1-2002, "Productos y Servicios. Leche, Fórmula Láctea y Producto Lácteo Combinado. Especificaciones Sanitarias," Norma Oficial Mexicana, 2002.

[27] V. Montaño, M. Chirico and R. Gemio, "Estudio Toxicológico de Presencia de Aflatoxina M1 en Leche Bovina Recolectada del Municipio de Achacachi," Revista Boliviana de Química, Vol. 24, No. 1, 2007, pp. 89-93. 